\title{
CHRONOLOGY OF IMPORTANT DATES
}

1857 Communist Club of New York founded by FortyEighters Friedrich Sorge and Joseph Weydemeyer.

1872 Headquarters of Marx's First International (1864) transferred from London to New York; supported by a few hundred German and other immigrant workers, but few native-born Americans.

1877 Socialist Labor Party established in New York City as an alliance of Marxist (trade union) and Lassallean (political) socialists; reaches peak membership, still largely immigrant, of approximately 6,500 in $1890 \mathrm{~s}$.

1886 May: Haymarket riot in Chicago, followed by Red Scare; November: American Federation of Labor (AFL) founded under cigarmaker Samuel Gompers; a conservative craft union body, it follows a nonpartisan political policy of "reward-your-friends, punish-your-enemies."

1893-94 AFL rejects T. J. Morgan's Political Programme calling for an independent labor party and collective ownership of industry; also refuses to endorse Populists.

1895 Socialist Labor Party leader and editor of The People Daniel De Leon, angered by defeat of Morgan Programme, establishes Socialist Trades and Labor Alliance as rival to AFL.

1897 Eugene V. Debs founds Social Democracy of America.

1898 Social Democratic Party founded by Victor Berger, Morris Hillquit, and others; gains support of Debs. 
1901 Socialist Party of America established, with headquarters in Chicago; a coalition of anti-De Leonite Marxists, Social Democrats, Christian socialists, and Bellamyite Nationalists, it repudiates dual unionism and seeks to "bore from within" the AFL.

1905 Industrial Workers of the World (IWW), known as "Wobblies," founded in Chicago as a revolutionary industrial union and rival to the AFL; initially incorporates De Leon's Socialist Trades and Labor Alliance, AFL seceders, and the Western Federation of Miners, led by Big Bill Haywood; at its peak, includes about 70,000 members, many of them migrant workers, compared to AFL's two million in 1917.

1906-10 Conflict within IWW, which endorses syndicalism in 1908, brings withdrawal of Western Federation of Miners, bitter conflict with AFL, and expulsion of De Leonites, who set up rival faction in Detroit; Wobblies undertake "free speech fights."

1912 March: IWW victory in Lawrence textile strike, aided by Haywood, Ettor and Giovanitti, and Emma Goldman; May: Socialist Party convention breaks with IWW, alleging anti-political stand and advocacy of violence; November: Debs receives 897,011 votes as Socialist Party presidential candidate, highest proportion of the popular vote ever received by a Socialist Party candidate.

1917-19 Because of opposition to April 1917 entry of U.S. into First World War and endorsement of October 1917 Russian revolution, most Socialist Party leaders are jailed; subsequent Red Scare emasculates party, dropping its peak membership of 125,740 in 1912 to 74,519 in 1918 .

1919 April: Lenin's recently formed Third International urges all socialists to endorse "immediate revolution" under Moscow's leadership; May: rejecting this, Socialist Party expels Foreign-Language Federations and 
other revolutionary elements, loses one-third of remaining members; July-September: Communist Party of America and Communist Labor Party set up by breakaway Socialists.

1921 Workers Party of America, later Communist Party U.S.A., unites most revolutionary socialists, except Trotskyites, who form the Socialist Workers Party (1937); initially, Communist Party is composed of exWobblies, intellectuals, Jews and other immigrants; Socialist Party, down to 12,000 members, never fully recovers.

1928-35 Communist Party, now in its revolutionary Third Period, replaces "boring from within" policy of Trade Union Educational League (1920) by dual unionist Trade Union Unity League (1928); limited success among coal, textile, and maritime workers; Communist and Socialist Parties try to organize unemployed from Great Depression.

1936 President Roosevelt's New Deal, bringing social security, relief, farm and labor legislation, attracts many farmers and workers, including southern blacks, into Democratic Party; in 1936 election, FDR receives nearly 28 million votes, compared to 187,342 for Socialist Norman Thomas, and 80,181 for Communist Earl Browder.

1936-37 Socialist Party, under Norman Thomas and H. L. Mitchell, organizes Southern Tenant Farmers Union, its only major trade union success of $1930 \mathrm{~s}$.

1936-39 Communist Party, following Popular Front policy, secures major influence in one-third of unions of Congress of Industrial Organizations (CIO), formed in 1936 by John L. Lewis, Philip Murray, and Sidney Hillman as an industrial union federation seceding from the AFL; Lee Pressman, Len DeCaux, and other Communists become part of official CIO leadership; 
xviii / CHRONOLOGY OF IMPORTANT DATES

Communist Party support for civil rights attracts votes of some blacks.

1939-41 Nazi-Soviet pact leads Communist Party to oppose U.S. rearmament.

1942-45 After German invasion of Russia (1941), Communist Party and much of Socialist Party support U.S. in Second World War, downplaying domestic grievances of workers.

1945-48 Emerging from war with a peak membership of 70,000, Communist Party rapidly loses support by defending Soviet interests in emerging Cold War.

1948 By endorsing third-party Progressive candidacy of Henry A. Wallace, Communist Party forfeits much union support.

1949 Communist-influenced unions expelled from AFL.

1950 Ten Communist-led unions expelled from CIO.

1950-56 Most remaining Socialists join the Democratic Party; McCarthyism destroys most remaining Communist influence in unions and among intelligentsia. 